\title{
Cumhurbaşkanlığı Ofislerinin Yapısına İlişkin Değerlendirme
}

\section{Assessment on the Structure of Presidential Offices}

\author{
Dr. Öğr. Üyesi Osman NACAK (iD) 1
}

\begin{abstract}
$\ddot{O} z$
Türkiye'de 24 Haziran 2018 tarihinde gerçekleştirilen seçimler sonrasında Cumhurbaşkanlığı hükümet sistemi uygulanmaya başlamıştır. Hemen akabinde yeni sistemin ilk kararnamesi olan 1 No'lu Cumhurbaşkanlığı Kararnamesi yayımlanmıştır. Bu kararnameyle Cumhurbaşkanlığı teşkilatı yeniden düzenlenmiş, Cumhurbaşkanlığı teşkilatı içinde yeni kurum ve kurullar oluşturulmuştur. Cumhurbaşkanlığı Kararnamesiyle ortaya çıkan kurumlardan birisi de Cumhurbaşkanlığı ofisleridir. Ofislerin en önemli görevi, kamu politikalarının oluşturulmasında Cumhurbaşkanına yardımcı olmaktır. Bu nedenle merkezi yönetimin başkent teşkilatında Cumhurbaşkanlığı teşkilatı içerisinde yer almaktadır. Ancak Cumhurbaşkanlığı ofislerinin aynı zamanda kamu tüzel kişiliği ile idari ve mali özerkliğe sahip oldukları görülmektedir. Cumhurbaşkanlığı ofislerinin bu yapısı, bazı soru ve sorunları gündeme taşımaktadır. Çalışmanın konusu yeni hükümet sistemi sonrasında ortaya çıkan Cumhurbaşkanlığı ofisleri ile bu ofislerin yapısının incelenmesidir. Çalışmanın amacı Cumhurbaşkanlığı ofisleri ile bu ofislerin yapısına ilişkin sorunların neler olduğunun derinlemesine analizidir. Çalışmada Cumhurbaşkanlığı ofislerinin yapısal yönünün idare hukuku öğretisiyle örtüşmediği, mevcut yapısı nedeniyle Türk idare teşkilatı içindeki yerinin sorunlu olduğu ve Cumhurbaşkanıyla olan ilişkisinin sağlıklı bir biçimde gerçekleşemediği yönünde bulgulara ulaşılmıştır. Yapılan değerlendirmelerden Cumhurbaşkanlığı ofislerinin yapısından kaynaklanan sorunlar ile tartışmaların sonlandırılabilmesi ve kuruluş amacına uygun bir kurum haline getirilebilmesi için Cumhurbaşkanlığı ofislerinin yapısında düzenlemeye ihtiyaç olduğu sonucuna ulaşılmaktadır.
\end{abstract}

Anahtar Kelimeler: Cumhurbaşkanlığı, Cumhurbaşkanlığı ofisleri, kamu yönetimi

Makale Türü: Araştırma

\begin{abstract}
Presidential System of Government in Turkey after the elections held on June 24, 2018 began to be implemented. Presidential Decree No.1, the first decree of the new system, was issued immediately after. With this decree, the Presidency organization was reorganized and many new institutions and boards were established within the Presidency organization. One of the institutions that emerged with the Presidential decree is the Presidential Offices. The most important task of the offices is to assist the President in formulating Public policies. For this reason, it is included in the Presidency organization in the capital organization of the central government. However, it is observed that the Presidency offices also have public legal personality and administrative and financial autonomy. This structure of the Presidential offices raises some guestions and problems. The subject of the study is to examine the Presidential offices that emerged after the new government system and the structure of these offices. The aim of the study is to analyse the problems related to the Presidency offices and the structure of these offices. In the study, findings were reached that the structural aspect of the Presidential offices does not coincide with the administrative law doctrine, while its place in the Turkish Administrative Organization is problematic and it will have a poor relationship with the President due to its current structure. From the evaluations made, it is concluded that there is a need for a regulation in order to end all these problems and discussions arising from the structure of the Presidential offices and to make them suitable for the purpose of establishment.
\end{abstract}

Keywords: Presidency of the Republic, presidential offices, public administration

\footnotetext{
${ }^{1}$ Aydın Adnan Menderes Üniversitesi, Nazilli İktisadi ve İdari Bilimler Fakültesi, onacak@adu.edu.tr

Atıf için (to cite): Nacak, O. (2021). Cumhurbaşkanlığı ofislerinin yapısına ilişkin değerlendirme. Afyon Kocatepe Üniversitesi Sosyal Bilimler Dergisi, 23(3), 1023-1041.
} 
Paper Type: Research

\section{Giriş}

2017 yılında gerçekleştirilen anayasa değişikliği referandumuyla parlamenter hükümet sisteminden Cumhurbaşkanlığı hükümet sistemine geçilmesine karar verilmiştir. Yeni hükümet sisteminin yürürlük tarihi, birlikte yapılacak ilk Cumhurbaşkanlığı ve Türkiye Büyük Millet Meclisi (TBMM) seçimleri olarak belirlenmiştir. Cumhurbaşkanlığı ve TBMM seçimleri 24 Haziran 2018 tarihinde yapılmış ve yeni hükümet sistemi 09 Temmuz 2018 tarihinde yeni seçilen Cumhurbaşkanının TBMM’de yemin etmesiyle yürürlüğe girmiştir.

Yeni sistemle birlikte Cumhurbaşkanı, sistemin kendisine verdiği yetkiyle yeni hükümet sisteminin ilk kararnamesi olan 1 No'lu Cumhurbaşkanlı̆̆ Kararnamesini 10/07/2018 tarih ve 30474 sayılı Resmi Gazetede yayımlamıştır. "Cumhurbaşkanlığı Teşkilatı Hakkında Cumhurbaşkanlığı Kararnamesi” adını taşıyan ve yedi kısım, 539 maddeden oluşan 1 No'lu Cumhurbaşkanlığ1 Kararnamesiyle Cumhurbaşkanlığ 1 teşkilatı yeniden düzenlenmiştir. Kararnamenin birinci kısmında Cumhurbaşkanlığı Makamı, ikinci kısmında Cumhurbaşkanlığ İdari İşler Başkanlığı, üçüncü kısmında Cumhurbaşkanı Yardımcıları ve Cumhurbaşkanına vekalet konularının düzenlendiği görülmektedir. Kararnamenin dördüncü kısmında ise ilk defa yeni sistemle birlikte ortaya çıkan Politika Kurullarına yer verilmiştir. Kararnamenin beşinci kısmında Cumhurbaşkanlığına bağlı kurum ve kuruluşlar maddeler halinde sayılmıştır. Kararnamenin altıncı kısmında, sayısı yirmi birden on yediye ${ }^{2}$ düşürülen bakanlıklar, her biri ayrı bir bölüm olmak üzere yeniden düzenlenmiş, devamında bakanlıklara ilişkin ortak hükümlere, idari kurul, konsey ve komisyonlar ile bakanlıklara bağlı, ilgili ve ilişkili kuruluşlara yer verilmiştir. Kararnamenin yedinci ve son kısmında ise yeni sistemle birlikte ilk kez ortaya çıkan ve çalışmanın da konusunu oluşturan Cumhurbaşkanlığı Ofisleri düzenlenmiştir.

1 No'lu Cumhurbaşkanlığı Kararnamesiyle Türk kamu yönetimi teşkilatına Cumhurbaşkanlığı politika kurulları ile Cumhurbaşkanlığı ofisleri adında iki yeni birim eklenmiştir. Her iki birimin de Cumhurbaşkanına görevlerinde yardımcı olmak amacıyla oluşturulmuş kurmay-yardımcı birimler olduğunu söylemek mümkündür. Ancak iki birimi birbirinden ayıran oldukça önemli bir farklılık bulunmamaktadır. 1 No'lu Cumhurbaşkanlığ 1 Kararnamesiyle Cumhurbaşkanlığı politika kurullarına kamu tüzel kişiliği ile idari ve mali özerklik verilmezken, Cumhurbaşkanlığı ofislerine kamu tüzel kişiliği ile idari ve mali özerklik verilmiştir. Cumhurbaşkanlığı ofislerinin yapısına yönelik sorun ve tartışmalar da işte tam bu noktada ortaya çıkmaktadır.

\section{Yöntem}

Çalışmanın konusu yeni hükümet sistemi sonrasında kurulan Cumhurbaşkanlığ ofislerinin yapısal analizidir. Çalışmanın amacı 1 No'lu Cumhurbaşkanlığı Kararnamesiyle Cumhurbaşkanına yardımcı bir kurum olarak merkezi yönetimin başkent teşkilatı içinde kurulan ancak yine aynı kararnameyle kamu tüzel kişiliği ile idari ve mali özerklik verilen Cumhurbaşkanlığı ofislerinin yapısına ilişkin sorunların derinlemesine incelenmesidir. $\mathrm{Bu}$ amaçla çalışmada temel olarak şu sorulara cevap aranmıştır: Devlet tüzel kişiliğinin haricince ayrı kamu tüzel kişiliğine sahip olan ofisler, merkezi yönetim teşkilatı içinde yer alabilir mi? Cumhurbaşkanıyla ofisler arasındaki ilişki nasıl gerçekleştirilecektir? Bu ilişkinin niteliği ne olacaktır? Cumhurbaşkanlığı ofislerine yönelik idarenin bütünlüğü ilkesi çerçevesinde uygulanacak denetim türü hangisidir?

\footnotetext{
${ }^{2}$ Çalışma son okuma aşamasındayken, 21/04/2021 tarihli ve 31461 sayılı R.G'de 73 No'lu “Aile ve Sosyal Hizmetler Bakanlığı ile Çalışma ve Sosyal Güvenlik Bakanlığının Kurulması ile Kamu Personel İşlemlerinin Yürütülmesine İlişkin Bazı Cumhurbaşkanlığı Kararnamelerinde Değișiklik Yapılmasına Dair Cumhurbaşkanlığı Kararnamesi” yayımlanmıștır. Bu kararnameyle Aile, Çalıșma ve Sosyal Hizmetler Bakanlığı, Aile ve Sosyal Hizmetler Bakanlığı ile Çalışma ve Sosyal Güvenlik Bakanlığı şeklinde ikiye ayrılmıştır. Bu değişiklik sonrasında on altı olan bakanlık sayısı on yediye yükselmiştir.
} 
Çalışmanın kapsamı ofislerin yapısal analiziyle sınırlı tutulmuştur. Ofislerin görevleri ise çalışmanın kapsamı dışındadır. Çalışmada nitel araştırma yöntemine ver yerilmektedir. Çalışmaya yönelik verilerin toplanmasında doküman incelemesi yöntemi, elde edilen verilerin analizinde ise içerik analizi yöntemi tercih edilmiştir. Çalışmanın temel veri kaynakları konuya yönelik yasal düzenlemeler, kitap ve makalelerdir.

Çalışma sonucunda; Cumhurbaşkanlığı ofislerinin yapısal yönünün idare hukuku öğretisiyle örtüşmediği, mevcut yapısı nedeniyle Türk idare teşkilatı içindeki yerinin sorunlu olduğu ve Cumhurbaşkanıyla olan ilişkisinin sağlıklı bir biçimde gerçekleşemediği yönünde temel bulgulara ulaşılmıştır. Elde edilen bulgulardan hareketle Cumhurbaşkanlığ 1 ofislerinin yapısından kaynaklanan sorunlar ile tartışmaların sonlandırılabilmesi ve kuruluş amacına uygun bir kurum haline getirilebilmesi için Cumhurbaşkanlığı ofislerinin yapısında düzenlemeye ihtiyaç olduğu sonucu ortaya çıkmaktadır.

Çalışma genel olarak üç ana başlıktan meydana gelmektedir. İlk olarak 1 No'lu Cumhurbaşkanlığ 1 Kararnamesinden hareketle Cumhurbaşkanlığ 1 ofislerinin kuruluş gerekçesi ve ana hatlarıyla yapısı ele alınmaktadır. Sonrasında kamu tüzel kişiliği ile idari ve mali özerklik kavramları ayrıntılı bir biçimde irdelenmektedir. Son bölümde ise Cumhurbaşkanlığı ofislerinin mevcut yapısından kaynaklandığı düşünülen sorunlar üç alt başlıkta derinlemesine analiz edilmektedir.

\section{Cumhurbaşkanlığı Ofislerine Genel Bir Bakış}

Cumhurbaşkanlığ1 ofisleri, 10/07/2018 tarih ve 30474 sayılı R.G.'de yayımlanarak yürürlüğe giren 1 No'lu “Cumhurbaşkanlığ Kararnamesi” ile kurulmuşlardır. Cumhurbaşkanlığı ofislerine ilişkin bir değerlendirmede bulunabilmek için ilk olarak kuruluş gerekçesine değinmek ve sonrasında da bu gerekçeyle uyumlu bir yapısı olup olmadığına bakmak da yarar vardır.

\subsection{Cumhurbaşkanlığı Ofislerinin Kurulma Nedeni}

Türk idare teşkilatında daha önce var olmayan ve ilk kez 1 No'lu Cumhurbaşkanlığ Kararnamesiyle ortaya çıkan Cumhurbaşkanlığ ofislerinin kuruluş gerekçesinin esas olarak hükümet sistemi değişikliği sonrasında Cumhurbaşkanının artan görev ve yetkileri olduğunu söylemek mümkündür. Çünkü Cumhurbaşkanlığı hükümet sistemiyle birlikte yürütme erkinde oldukça önemli değişimler meydana gelmiş, yürütme yetkisi doğrudan Cumhurbaşkanına verilerek Başbakan ve Bakanlar Kurulunun varlığına son verilmiştir. Yürütme erkindeki bu değişiklikle Cumhurbaşkanına yürütme alanında birçok yeni görev, yetki ve sorumluluk verilmekte, Cumhurbaşkanının görev ve yetki alanı oldukça genişlemektedir. Yeni hükümet sisteminde Cumhurbaşkanı kamu politikalarının oluşturulması, kamu hizmetlerinin yerine getirilmesi, toplumun talep ve ihtiyaçlarının karşılanması gibi konularda temel aktör haline gelmiştir. Cumhurbaşkanının kendisine verilen bütün bu görevleri yerine getirebilmesi için Cumhurbaşkanlığ 1 teşkilatının günün koşullarına uygun olarak yeniden düzenlenmesi ve bazı yeni kurumların kurulması bir zorunluluk haline gelmiştir. Cumhurbaşkanlığ ofislerinin bu süreçte Cumhurbaşkanına artan görev ve yetkilerinin kullanılmasında yardımcı olmak, görüş ve önerileriyle danışmanlık yapmak maksadıyla ortaya çıktığını söylemek mümkündür. Ofisler, kendilerine verilen görevleri yerine getirirken Cumhurbaşkanı tarafından belirlenen amaç, politika ve stratejilere uygun davranmak zorundadır. Bu nedenle Cumhurbaşkanlığ 1 ofisleri, Cumhurbaşkanlığı teşkilatı içinde ve Cumhurbaşkanıyla yakın bir çalışma alanı içerisinde düzenlenmektedir (Erol, 2020, s. 120; Sobac1 vd., 2018, s. 2).

Cumhurbaşkanlığı ofislerinin kurmay-yardımc1 bir kurum olarak planlandığ 1 görülmektedir. Özellikle kamu politikalarının oluşturulması, hayata geçirilmesi ve uygulanmasının takibi yönünden kurmay bir kurum olan ofislerin, kamu politikalarına yönelik araştırma, veri toplama, proje geliştirme, proje üretme, çalışmaları yürütme, kurumlar arasında koordinasyonu sağlama ve işbirliğini gerçekleştirme gibi görev ve yetkileri yönünden de 
yardımcı bir kurum olarak karşımıza çıkmaktadır. Parlamenter sistemdeki bakanlıkların kamu politikalarının oluşturulmasındaki rolünü, yeni hükümet sisteminde üstlenen kurumlardan birisinin de Cumhurbaşkanlığı ofisleri olduğu görülmektedir. $\mathrm{Bu}$ bağlamda 1 No'lu Cumhurbaşkanlığı Kararnamesinde ofislerin, bakanlıklar ve diğer paydaşlarla gerekli olan koordinasyonu sağlayarak kamu politikalarının oluşturulmasında Cumhurbaşkanına yardımcı olmakla görevli ve yetkili oldukları açıkça ifade edilmektedir (Erol, 2020, s. 119-120; Sobacı vd., 2018, s. 2-4; Turan, 2018, s. 63, 74; Üstün, 2019, s. 33). Ayrıca bakanlıkların kamu politikalarına ilişkin uygulamalarının takibi görevinin de ofislere verildiği görülmektedir (Akman, 2019, s. 49). Bu bağlamda yeni hükümet sisteminde ofislerin, hem oluşturulacak kamu politikalarına kaynaklık edecek olan projelerin geliştirilmesinde hem de politika uygulamalarının takibi ve raporlanmasında hayati bir rol üstlenmekte olduğunu söylemek mümkündür (Örselli vd., 2018, s. 315-316).

\subsection{Cumhurbaşkanlığı Ofislerinin Yapısı}

Cumhurbaşkanlığı ofisleri 1 No'lu Cumhurbaşkanlığı Kararnamesinin yedinci kısmında, 525. maddesi (dahil) ile 536. maddesi (dahil) arasında düzenlenmektedir. Esasında 1 No'lu Cumhurbaşkanlığı Kararnamesinin ilk halinde yedinci kısmın hiçbir alt bölümünün bulunmadığ1 ve tek bölüm halinde doğrudan maddeler şeklinde düzenlendiği görülmektedir. Ayrıca ofislerin görevlerinin de son derece yüzeysel bir şekilde ele alındığını söylemek mümkündür. Ancak 24/10/2019 tarihli 30928 sayılı R.G'de yayımlanarak yürürlüğe giren 48 No'lu "Cumhurbaşkanlığ1 Teşkilatı Hakkında Cumhurbaşkanlığı Kararnamesinde Değişiklik Yapılmasına Dair Cumhurbaşkanlığı Kararnamesi” ile Cumhurbaşkanlığı ofisleri çok daha ayrıntılı bir biçimde yeniden düzenlenmiştir.

1 No'lu Cumhurbaşkanlığı Kararnamesine göre Dijital Dönüşüm, Yatırım, Finans ve İnsan Kaynakları olmak üzere dört adet ofis kurulmuştur. Ofisler doğrudan Cumhurbaşkanına bağlıdır. Her ofisin başında Cumhurbaşkanı tarafından atanan bir başkan bulunmaktadır. Başkan, ofisin en üst hiyerarşik amiri olup, görevleri bakımından Cumhurbaşkanına karşı sorumludur. Ayrıca ofisin bütçesi de başkan tarafından hazırlanmaktadır. Her bir ofis, ana hizmet birimi ile danışma ve yardımcı hizmet birimlerinden oluşmaktadır. Ofisler, diğer kamu kurum ve kuruluşlarından görev alanına ilişkin her türlü bilgi ve belgeyi isteme yetkisine sahiptir. Ayrıca kararnamede her bir ofis ile ofisin görev ve yetkilerinin ayrıntılı bir biçimde düzenlendiği görülmektedir.

1 No'lu Cumhurbaşkanlığı Kararnamesinin yedinci kısmının son alt bölümünde sorumluluk ve koordinasyon, personelin istihdamı, çalıştırılması ve görevlendirilmesi, eğitim ve mecburi hizmet, bütçe ve denetim, bilgi isteme ve gizliliğe uyma, kadrolar, yöneticilerin sorumluluğu, yetki devri, düzenleme görev ve yetkisi, yurtdışı teşkilatı ve atıflar gibi bütün Cumhurbaşkanlığı ofisleri için geçerli olan ortak hükümlerin düzenlendiği görülmektedir.

1 No'lu Cumhurbaşkanlığı Kararnamesinin yedinci kısmının birinci bölümü Cumhurbaşkanlığ 1 ofislerinin kuruluşunu düzenlemektedir. İki maddeden (525.md ve 526. Md.) oluşan birinci bölümde "Kuruluş" başlığını taşıyan 525. madde son derece önemlidir. Zira bu maddede hem Cumhurbaşkanlığı ofislerinin sayısına ve adlarına hem de bu ofislerin sahip olduğu özelliklere yer verilmektedir. 525. maddeye göre; “... verilen görevleri yerine getirmek üzere Cumhurbaşkanlığına bağlı, özel bütçeli, kamu tüzel kişiliğine haiz, idari ve mali özerkliğe sahip Dijital Dönüşüm Ofisi, Finans Ofisi, İnsan Kaynakları Ofisi ve Yatırım Ofisi kurulmuştur." Esas olarak Cumhurbaşkanlığ 1 ofislerine ilişkin kamuoyunda tartışmalara sebep olan da bu maddedir.

Cumhurbaşkanlığı ofislerine ilişkin kamuoyunda önemli tartışmalara sebep olan konulardan ilki ofislerin kamu tüzel kişiliğidir. Çünkü merkezi yönetimin başkent teşkilatı içerisinde yer verilen Cumhurbaşkanlığı ofislerinin, aynı zamanda merkezi yönetimin tüzel kişiliğinin dışında ayrı bir kamu tüzel kişiliğine sahip olduğu görülmektedir. Cumhurbaşkanlığı ofislerine ilişkin kamuoyunda tartışmalara sebep olan konulardan ikincisi de ofislerin idari ve 
mali özerkliğidir. Çünkü aynı şekilde merkezi yönetimde yer alan bir birimin merkezi yönetimin hiyerarşisinin dışında bırakılması nasıl gerçekleşecektir? Bu sebeple konunun daha iyi anlaşılabilmesi için öncelikle devlet tüzel kişisi ve kamu tüzel kişisi kavramları ile idari ve mali özerklik kavramlarının açıklanmasında yarar vardır.

\section{Kamu Tüzel Kişiliği İle İdari ve Mali Özerklik Kavramlarının Analizi}

Cumhurbaşkanlığı ofislerine ilişkin bir değerlendirme yapmadan önce devlet tüzel kişisi ve kamu tüzel kişisi ile idari ve mali özerklik kavramların açıklanması gerekmektedir. Çünkü bu kavramların tam olarak ne olduğu anlaşılmadan yapılacak her analiz bizi yanlış sonuç veya sonuçlara götürecektir.

\subsection{Devlet ve Kamu Tüzel Kişisi}

Hukuk, haklara ve borçlara sahip olabilen varlıkları "kişi" olarak tanımlamaktadır. Hukuken kişi olmak son derece önemlidir. Çünkü kişiler, herhangi bir konuda irade açılayabilir, hukuki ilişkilere taraf olabilir, hukuken geçerli işlemler yapabilir, kendi namına malvarlığı edinebilir, malvarlığı üzerinde dilediği tasarrufta bulunabilir, kendisine ait bir bütçeye sahip olabilir, irade açıklamaları ile kendilerini hak ve borç altına sokabilir, hukuken sorumluluk sahibi olabilir ve bu bağlamda mahkemeler nezdinde davalı ve davacı sıfatına sahip olabilirler. Hukukta iki tür kişinin var olduğu kabul edilmektedir. Bunlardan birincisi gerçek kişilerdir. Hakiki şahıslar olarak da ifade edilen gerçek kişiler elbette ki, insanlardır. Günümüz modern hukuk düzeninde hiçbir ayrım gözetilmeksizin bütün insanlar kişi olarak kabul görmektedir. İkincisi ise tüzel kişilerdir. Hükmi şahıslar olarak da ifade edilen tüzel kişiler, insanların veya malların ortak bir amaç için bir araya gelmesiyle oluşturulmuş ve kendisini oluşturan kişilerin veya varlıkların dışında ayrı bir varlığa sahip olan kişi ya da mal topluluklarıdır. Tüzel kişi kavramının tarihi kökenlerinin oldukça eski olduğu ve ilkçağlara kadar dayandığı kabul edilmektedir. Hukuk, tüzel kişileri bağımsız bir varlık olarak kabul eder ve gerçek kişilerin sahip oldukları haklardan (cins, yaş, hısımlık gibi insana özgü niteliklere bağlı olanlar hariç) yararlandırır. Tüzel kişiler de tıpkı gerçek kişiler gibi hak ve fiil ehliyetine sahip olup, bütün bunları yetkili organları aracılığıyla kullanır. Tüzel kişiler kendi içinde ikiye ayrılmaktadır. Esasında bu ayrım tüzel kişiye uygulanan hukuktan kaynaklanmaktadır. Özel hukuka tabi olan tüzel kişilere özel hukuk tüzel kişisi, kamu hukukuna tabi olan tüzel kişilere kamu kamu hukuku tüzel kişisi adı verilmektedir (Akyılmaz vd., 2018, s. 187; Çağlayan, 2016, s. 375-376; Gençay, 2018, s. 156; Gözler, 2003, s. 132-133; Medeni Kanun, md. 47., 48., 50.).

Kamu hukuku tüzel kişileri, kamu hukuku kurallarına göre ortaya çıkan ve bu kurallar çerçevesinde faaliyette bulunan tüzel kişilerdir. Kamu hukuku tüzel kişileri anayasanın 123. maddesine göre kanunla veya Cumhurbaşkanlığ 1 kararnamesiyle kurulur ve aynı şekilde kaldırılır. Bununla birlikte kamu hukuku tüzel kişileri, özel hukuk tüzel kişilerinden farklı olarak, özel hukuku aşan üstün yetkiler şeklinde ifade edilen kamu gücü ayrıcalıklarından yararlanır. Kamu hukukuna tabi olan tüzel kişiler de kendi içinde kamu tüzel kişileri ve diğer kamu tüzel kişileri olmak üzere ikiye ayrılmaktadır (Çağlayan, 2016, s. 377, 395).

Kamu hukukuna tabi tüzel kişilerden kamu tüzel kişisi, literatürde yaygın olarak devlet tüzel kişisi şeklinde ifade edilmektedir. Devlet, gerçek kişilerin bir araya gelmesiyle oluşur. Ancak devletin kendisini meydana getiren kişilerin üstünde ve ondan ayrı hukuki kişiliği bulunmaktadır. Dolayısıyla günümüzde devlet, en büyük kamu tüzel kişisi olarak kabul görmektedir. Devlet, hukuki kişiliği sayesinde gerçek kişilerin hukuken sahip olduğu bütün hak ve yetkilere sahip olabilmektedir. 1982 Anayasasının birçok maddesinde (md. 29/4, 82/1, 128/1, 161/1 gibi) devlet tüzel kişisinden söz edilmektedir. Peki devlet tüzel kişisiyle kastedilen kimdir? İdare hukukuna göre merkezi yönetimin tamamı devlet tüzel kişisi olarak tanımlanmaktadır. Dolayısıyla merkezi yönetimi meydana getiren başkent örgütü ile taşra örgütü ve yardımcı kuruluşlar, devlet tüzel kişisi olarak ifade edilmektedir. Gerçekten de merkezi yönetim, bir bütün halinde tek bir tüzel kişiliğe sahiptir. Merkezi yönetimde devlet tüzel kişiliğinin haricinde ve ondan ayrı başka bir tüzel kişilik bulunmamaktadır. Bu sebeple 
Cumhurbaşkanlığının, bakanlıkların, yardımcı kuruluşların, merkezi yönetimin taşra teşkilatında yer alan il, ilçe ve bölgenin devlet tüzel kişiliğinin dışında kendilerine ait bir tüzel kişiliği yoktur. Bunların tamamı devlet tüzel kişiliği içinde yer almakta ve devlet tüzel kişiliğini temsil etmektedir (Çağlayan, 2016, s. 377-379; Görmez, 2003, s. 134-136).

Kamu hukukuna tabi olan tüzel kişilerden diğer kamu tüzel kişiler için ise yaygın olarak kamu tüzel kişileri ifadesi kullanılmaktadır. Türkiye'de devlet tüzel kişiliğinin bir diğer ifadeyle merkezi yönetimin dışında örgütlenmiş kurumların tamamının kamu tüzel kişilikleri vardır. Esasında bu bir zorunluluktur. Çünkü merkezi yönetimin dışındaki kuruluşlar, kendilerine verilen tüzel kişilik sayesinde tıpkı merkezi yönetim kuruluşları gibi benzer yetki ve ayrıcalıklardan yararlanabilmekte ve böylelikle kendilerine verilen görevleri yerine getirebilmektedirler. Aksi takdirde görevlerini yerine getirebilmeleri mümkün değildir. Devlet tüzel kişiliği bütüncüllük göstermekteyken, merkezi yönetimin dışındaki örgütlerin her birinin kendisine ait tüzel kişiliğinin bulunduğu görülmektedir. İdare hukukunda bu kuruluşlar, yerinden yönetim kuruluşları şeklinde ifade edilmektedir. İl özel idareleri, belediyeler, köyler, üniversiteler, TRT, KİT'ler, kamu kurumu niteliğindeki meslek kuruluşları gibi kuruluşlar, buna örnek olarak verilebilir. (Akyılmaz vd., 2018, s. 136-138, 159; Görmez, 2003, s. 137; Tortop, 1999, s. 10-11).

Yapısı itibarıla idare, oldukça parçalı bir halde gibi görünse de, bu parçalı yapılanmanın birbirinden tamamen ayrı olduğunu düşünmek mümkün değildir. Özellikle siyasal açıdan merkeziyetçi (üniter) bir devlette idarenin bir bütün olması zorunluluktur. Bu nedenle de idarenin en temel ilkelerinden birisi idarenin bütünlügüüür. Anayasamızda bu durum, "idare, kuruluş ve görevleriyle bir bütündür" şeklinde açıkça ifade edilmektedir (1982 Anayasası, md. 123/1). İdarenin bütünlüğünü sağlayan kurumlar arasındaki ilişki ile bu ilişkiden kaynaklı olarak ortaya çıkan denetimdir (Gözübüyük, 2003, s. 40-41).

\subsubsection{Aynı Kamu Tüzel Kişi İçindeki İlişsi}

Aynı tüzel kişi içindeki kurumların veya kamu görevlilerinin arasında bir kademelenme veya sıradüzen, bir diğer ifadeyle astlık-üstlük ilişkisi vardır. Kurumların veya kamu görevlilerinin ast-üst şeklindeki örgütlenmesi hiyerarşi olarak ifade edilmektedir. Hiyerarşi, aynı tüzel kişi içinde yer alan kurumlar veya aynı kurum içinde görev yapan kamu görevlileri arasındaki derecelenmeye işaret etmektedir. Her bir kamu tüzel kişisi, hiyerarşik açıdan bir bütündür (Gözler; 2018, s. 197-198; Gözübüyük, 2003, s. 332). Hiyerarşinin en önemli özelliği üstte yer alan amir veya kurumlara hiyerarşi yetkisi vermesidir. Hiyerarşi yetkisi sınırları son derece geniş bir yetkidir. Bu yetki, üst konumunda olan kurumlara veya kişilere astları üzerinde son derece önemli ve geniş bir hareket alanı yaratmaktadır. Tam olarak çerçevesi net olmayan hiyerarşi yetkisi, emir ve talimat verme, yönlendirme, astların işlemlerini onama, iptal etme, kaldırma, değiştirme, uygulamasını durdurma, kanunilik ve yerindelik açısından denetleme gibi birçok imkanı vermektedir. Diğer taraftan hiyerarşi ilişkisi ast konumunda olanlara da bazı sorumluluklar yüklemektedir. Ast konumunda olanlar eylem ve işlemlerini kendi görüş ve anlayışı çerçevesinde değil, üstün yönlendirmesine, emir ve talimatlarına göre gerçekleştirmek zorundadır. Ast konumunda olanlar kural olarak kendisine verilen emir ve talimatlara uygun davranmakla yükümlüdür. Çünkü üstün anlayışı ast için bağlayıcıdır. Ayrıca ast, üstüne karşı her zaman hesap vermekle yükümlü ve sorumlu tutulmuştur. Bununla birlikte hiyerarşi ilişkisi üste, astı üzerinde geniş bir denetim yapma yetkisi vermektedir. Hiyerarşik denetim olarak ifade edilen bu yetki, hem kanuna uygunluk hem de yerindelik açısından gerçekleştirilebilmektedir. Dolayısıyla hiyerarşik üstün, astının bir işlemini veya eylemini, iptal etmesi, geri alması, yürütmesini durdurması, ertelemesi, değiştirmesi, onamaması için mutlaka kanunlara aykırı olmasına gerek yoktur. Sadece ihtiyaca uygun olduğunu düşünmediği yani yerinde bulmadığ 1 için de bütün bu yetkilerini kullanabilmektedir (Akyılmaz vd., 2018, s. 162-163; Gözler, 2018, s. 197-202; Gözübüyük, 2003, s. 332-333; Tortop vd., 2017, s. 70; Tortop, 1999, s. 6, 13). Bu nedenle hiyerarşik denetim yetkisinin de son derece geniş olduğu ve üste geniş yetkiler sağladığını söylemek mümkündür. Üstelik hiyerarşik denetim yetkisi genel bir yetki olup, bu 
yetkinin kullanılabilmesi için yasal bir dayanağa da ihtiyaç bulunmamaktadır. Dolayısıyla bu yetkinin nasıl, ne zaman, hangi biçimde kullanılacağı üstün takdirine bırakılmıştır.

Merkezi yönetim devlet tüzel kişisi adıyla tek ve bir bütün halindedir. Bu nedenle merkezi yönetim teşkilatı içerisinde yer alan bütün kurumlar arasında bir ast-üst ilişkisi bulunmaktadır (Çağlayan, 2016, s. 378-379; Gözler, 2018: s.135). Bir diğer ifadeyle merkezi yönetim teşkilatı içerisindeki kurumlar arasında hiyerarşi ilişsisi söz konusudur. Merkezi yönetim hiyerarşisinin en üstünde Cumhurbaşkanı bulunmaktadır. Cumhurbaşkanı ile Cumhurbaşkanlığ 1 teşkilatı içerisinde yer alan kurumlar ve Cumhurbaşkanlığ 1 teşkilatı dışında yer almakla birlikte merkezi yönetim içinde yer alan taşra teşkilatları arasında hiyerarşik bir ilişki söz konusudur. Bu ilişki Cumhurbaşkanına, bu kurumlar üzerinde hiyerarşi yetkisinin sağladığı bütün yetkileri kullanabilme imkanı vermektedir. Elbette ki, hiyerarşi yetkisi sadece en üst hiyerarşik amir olan Cumhurbaşkanı ile sınırlı değildir. Yönetici sıfatına sahip herkes, astları üzerinde hiyerarşi yetkisini kullanabilmektedir. Diğer taraftan hiyerarşik olarak üstte yer alan bir kurum astı konumundaki kurumlar üzerinde hiyerarşi yetkisini kullanabilmektedir. Örneğin bakanlığın en üst hiyerarşik amiri olan bakan, kendi bakanlığı ile kendisine bağlı birimlerde hiyerarşi yetkisini kullanabilmektedir. Yine bakanlık il yönetimi üzerinde, il yönetimi ilçe yönetimi üzerinde hiyerarşi yetkisini kullanabilmektedir. Bununla birlikte yine hiyerarşik bağ, ast konumunda olan kurumlara üst konumunda olan kurumlara karş1 sorumluluk yüklemektedir (Tortop vd., 2017, s. 70). Bu nedenle merkezi yönetim içerisinde yer alan gerek başkent gerekse taşra olmak üzere bütün kurumlar, esas itibarıyla en üst hiyerarşik amir olan Cumhurbaşkanına karşı görev ve yetkilerini kullanmaları bakımından sorumludur. Bu nedenle 1 No'lu Cumhurbaşkanlığı Kararnamesinin 503. maddesinde "bakanlar, kamu kaynaklarının etkili, ekonomik ve verimli kullanımı amacıyla, bakanlık hizmetlerini ... Cumhurbaşkanının genel siyasetine, Cumhurbaşkanı karar ve talimatlarına ... uygun olarak yürütmekle ... görevli ve Cumhurbaşkanına karşı sorumludur" ifadesi yer almaktadır (md.503/2).

Hiyerarşi ilişkisini sadece merkezi yönetim ile sınırlı düşünmek mümkün değildir. Çünkü hiyerarşi, aynı tüzel kişilik içerisindeki ast-üst ilişkisidir. Bu nedenle merkezi yönetimin dışında ayrı bir kamu tüzel kişisi olarak örgütlenmiş bütün kurumların kendi iç yapılanmasında ast-üst şeklinde bir yapılanma, bir diğer ifadeyle hiyerarşi iliş̧kisi söz konusudur. Bu kurumların en üst yöneticisi, o kamu tüzel kişisi içindeki en üst hiyerarşik amir sıfatına sahiptir. Dolayısıyla en üst hiyerarşik amir, kendi tüzel kişiliği içinde hiyerarşi yetkisinin sağladığı bütün yetkileri kullanabilme imkanına sahiptir. Ancak burada bir konuya açıklık getirmekte fayda vardır. Merkezi yönetiminin dışında örgütlenen yerinden yönetim kuruluşlarının her biri kamu tüzel kişiliğine sahip olduğu ve hiyerarşi ilişkisi de sadece aynı tüzel kişilik içinde mümkün olabildiğine göre, kamu tüzel kişiliği bulunan kurumların en üst hiyerarşik amirinin teorik olarak herhangi bir hiyerarşik amirlerinin bulunmadığını söylemek mümkündür. Örneğin belediye başkanının, üniversite rektörünün, TRT genel müdürünün, köy muhtarının, oda başkanının hiyerarşik üstü bulunmamaktadır. Çünkü tüzel kişiliğin bittiği yerde hiyerarşi iliş̧kisinin sona erdiği kabul edilmektedir. Bir diğer ifadeyle ayrı tüzel kişilikler arasında hiyerarşi ilişkisinden söz edilememektedir (Akyılmaz vd., 2018, s. 159).

\subsubsection{Ayrı Kamu Tüzel Kişileri Arasındaki İlişsi}

Hiyerarşi ilişkisi sadece aynı tüzel kişilik içinde mümkün olduğuna göre ayrı tüzel kişilerin idarenin bütünlüğü ilkesine uygun hareket ettirilebilmesinin bir yolunun olması gerekmektedir. Çünkü bunların tamamen bağımsız hareket edebildiklerini düşünmek mümkün değildir. Hele ki, merkezi yönetimin dişında kendisine ait tüzel kişiliği olan kurumların merkezi yönetimden tamamen bağımsız olduklarını düşünmek kesinlikle mümkün değildir. Ancak merkezi yönetim ile kamu tüzel kişiliğine sahip kurumlar arasında hiyerarşik bir bağın olmadığ 1 da ortadadır (Akyılmaz vd., 2018, s. 136-138, 162). Bu nedenle merkezi yönetim ile dışındaki kamu tüzel kişileri arasındaki bağın kurulabilmesi için idari vesayet ilişkisi geliştirilmiştir (Tortop vd., 2017, s. 74). O halde idari vesayet ilişkisi, merkezi yönetim ile merkezi yönetimin dışındaki kamu tüzel kişiliğine haiz kurumlar arasındaki ilişkidir. Dolayısıyla merkezi 
yönetiminin dışındaki iki ayrı kamu tüzel kişi arasında idari vesayet ilişkisinden söz etmek teoride mümkün değildir. ${ }^{3}$

Devlet tüzel kişisi olan merkezi yönetim ile merkezi yönetimin dışındaki kamu tüzel kişileri arasında uygulanan idari vesayet ilişkisi son derece sınırlı bir ilişkidir. Hiyerarşi ilişkisinde olduğu gibi üstlere geniş ve sınırları belirsiz yetkiler vermemektedir. Ayrıca idari vesayet ilişkisi emir ve talimat verme yetkisini de kapsamamaktadır. Çünkü kamu tüzel kişilerinin görevleri kanunla düzenlenmektedir $\mathrm{Bu}$ sebeple merkezi yönetim çok fazla müdahalede bulunamaz (Tortop, 1999, s. 12-13). Ayrıca kamu tüzel kişiliğine haiz kurumların hiyerarşi ilişkisinde olduğu gibi merkezi yönetime karşı görev ve yetkilerini yerine yetirme bakımından doğrudan sorumlu tutulmaları gibi bir durum da söz konusu değildir. İdari vesayet ilişkisinin doğal bir sonucu olarak bu kurumlar arasındaki denetim de faklı bir biçimde gerçekleşmektedir. Bir diğer ifadeyle merkezi yönetim ile yerinden yönetim arasında hiyerarşik bir bağ olmadığı için hiyerarşik denetimin olabilmesi mümkün değildir. Bu nedenle merkezi yönetimin yerinden yönetimi denetleyebilmesi için idari vesayet denetimi adı verilen yeni bir denetim biçimi ortaya çıkarılmıştır.

Kara Avrupası sistemine (idari rejim) özgü bir denetim türü olan idari vesayet denetimi, merkezi yönetimin yerinden yönetimi denetleme biçimi olarak ifade edilmektedir (Tortop, 1999, s. 13). Anayasada "merkezi idare, mahalli idareler üzerinde, ... kanunda belirtilen esas ve usuller dairesinde idari vesayet yetkisine sahiptir" ifadesi yer almaktadır (1982 Anayasası, md. 127/5). Dolayısıyla Anayasanın merkezi yönetime, yerel yönetim kuruluşları üzerinde idari vesayet denetimi yetkisi verdiği görülmektedir. Ancak gerek Anayasada gerekse diğer mevzuatlarda fonksiyonel yerinden yönetim kuruluşlarının idari vesayet denetimine tabi olduğuna ilişkin herhangi bir düzenleme bulunmamaktadır. Böyle olmakla birlikte yerel yönetim kuruluşlarının yapısı ve görevleri itibariyle merkezi yönetimden daha uzak oldukları göz önüne alındığında, yerel yönetimler üzerinde var olan idari vesayet denetiminin fonksiyonel yerinden yönetim kuruluşlarını da kapsadığı literatürde genel kabul görmektedir (Akyılmaz vd., 2018, s. 136-138, 169-170). İdari vesayet denetiminin amacı, devlet tüzel kişiliği dışındaki kamu tüzel kişilerinin, devlet tüzel kişisiyle ilişkisini ve yasalara uygun bir biçimde çalışmasını sağlayarak, idarenin bütünlüğünü temin etmektir (Gözübüyük, 2003, s. 334).

İdari vesayet denetimin çerçevesi yasama organı tarafından kanunla belirlenmek zorundadır. Çünkü anayasanın 127/5. maddesinde idari vesayet denetiminin kanunla düzenleneceği belirtilmektedir. Dolayısıyla idari vesayet denetimi yetkisinin her zaman kullanılamayacağı, kullanılabilmesi için açık bir kanuni dayanağa ihtiyaç olduğu görülmektedir. $\mathrm{Bu}$, idari vesayet denetimini hiyerarşik denetimden ayıran en önemli farktır. Kanunda düzenlenmeyen bir konuda idari vesayet denetimi yetkisinin kullanılması mümkün değildir. Merkezi idare içerisinde ancak kanunla kendisine yetki verilen birimler idari vesayet denetimi yapabilir ve bu yetki hiçbir biçimde yetki devrine konu olamaz. İdari vesayet denetiminin teoride sadece kanunlara uygunluk (kanunilik) denetimi şeklinde uygulanabileceği, yerindelik denetimi şeklinde uygulanmasının söz konusu olamayacağı belirtilmektedir. Bu nedenle idari vesayet denetiminin, son derece sinırlı ve istisnai bir denetim türü olduğu belirtilmektedir (Aky1lmaz vd., 2018, s. 173-174; Gözübüyük, 2003, s. 334; Tortop, 1999, s. 13).

\section{2. İdari ve Mali Özerklik}

Özerklik; kendi, ben, temel kişiliği oluşturan varlık anlamlarına gelen 'öz' ile güç, yeti, yetenek anlamlarına gelen 'erk' sözcüklerinin birleşmesinden meydana gelmektedir. Özerklik, ülkemizde muhtariyet şeklinde ifade edilmektedir. Osmanlıca kökenli bir sözcük olan muhtar, seçilmiş, kendisine verilen görevlerde serbest hareket eden kimse anlamına gelmektedir (Angın,

\footnotetext{
${ }^{3}$ Merkezi yönetim dışındaki iki ayrı kamu tüzel kişi arasında idari vesayet ilişkisinin olamayacağı ifade edilse de, son dönemde idari vesayet uygulamalarının iki ayrı kamu tüzel kişi arasında ortaya çıkabilecek biçimde genişletildiği görülmektedir. Uygulamada bunun örneklerine rastlamak mümkündür. YÖK ile Üniversiteler arasındaki ilişki ya da Büyükşehir belediyeleri ile İlçe belediyeleri arasındaki ilişki veya Barolar Birliği ile bir İl barosu arasındaki ilişki bu duruma örnek olarak verilebilir.
} 
2016, s. 644). İngilizcede 'autonomy' sözcüğüne karş1lı gelmektedir. Autonomy sözcüğü, etimolojik olarak kendi, kendini anlamlarına gelen 'auto' ile yönetme, yönetim, kuralını koyma, karar verme anlamlarına gelen 'nomus' sözcüklerinden meydana gelmekte olup, "kendi kuralını koyabilmesi, kendi kararını verebilmesi" olarak ifade edilmektedir (Angın, 2016, s. 644; İsbir, 2010, s. 1585-1586). Türk Dil Kurumu sözlüğünde özerklik; bir topluluğun veya kuruluşun ayr1 bir yasaya bağlı olarak kendi kendini yönetme hakkı, muhtariyet" şeklinde tanımlanmaktadır. İdare hukukunda ise özerklik; tüzel kişiliğe sahip kamu kurumlarının merkezi hükümetin siyasi müdahalesi olmadan kamu hizmeti üretebilmesi (Karahanoğulları, 2013, s. 65) veya bir kanunla bir kuruluşa kendi kendini yönetme hakkının tanınması, üstlendikleri hizmetlerin gerektirdiği düzenlemelerin söz konusu kurumların kendi organları tarafından serbestçe yapılabilmesi (Kalabalık, 2005, s. 130'dan aktaran Yontar ve Özer, 2018, s. 102,), ya da kendi kendine yetebilme ve yönetimde serbestlik (Eryılmaz, 2010: 79) şeklinde tanımlanabilmektedir. O halde özerkliği; en yalın haliyle bir üst organa bağlı olmakla birlikte kendi kendini yönetebilme ve bazı konularda serbest hareket edebilme yeteneği şeklinde tanımlamak mümkündür.

Esasında kurumlara tanınan özerk statünün tek başına çok anlamlı olmadığı, tüzel kişilikle birlikte önemli ve anlamlı bir hale geldiği görülmektedir (Keleş, 2006, s. 52; Öner, 2006, s. 10). Zira bu haliyle tüzel kişiliğe haiz ve özerkliğe sahip kurumlar yasama tarafından çıkarılan bir kanunla kendi kendini yönetebilme yetkisine sahip olabilmektedir. Dolayısıyla esas olarak özerkliğin sınırını belirleyen yasama organı olup, çıkardığı kanunla özerkliğin derecesini azaltıp, arttırabilir (Yontar ve Özer, 2018, s. 102). Merkezi yönetimin bürokratik işleyişinin ortaya çıkardığı olumsuzlukları en aza indirebilmek amacıyla geliştirilen özerklik (Ulusoy ve Akdemir, 2009, s. 261), söz konusu kurumlara merkezi yönetim içerisinde bir ayrıcalık sağlama düşüncesi değil, tam tersine kanunla verilen kamu hizmetinin etkinliğini sağlamaya yönelik bir araçtır (Demir, 2005, s. 275; Öner, 2006, s. 10; Tortop, 1999, s. 19; Yontar ve Dağ, 2014, s. 149-150). Bu noktada hemen şunu belirtmekte fayda vardır. Özerklik ile bağımsızlık kavramlarının birbirine karıştırılmaması gerekmektedir. Çünkü özerk kurum, her ne kadar belirli alanlarda serbest hareket edebilme yeteneğine sahip olsa da, mutlaka bir üst organa bağlidır. Ancak üst kurum ile arasındaki bağ, özerk olmayanlara nazaran oldukça farklı ve son derece sinırlıdır (Eryılmaz, 2010, s. 79; Keleş, 2006, s. 52; Öner, 2006, s. 11; Sobacı ve Köseoğlu, 2016, s. 17).

Yasal bir düzenlemeyle bir kuruma özerkliğin verilmiş olmasının ötesinde bir kurumun özerkliğinden söz edebilmek için bazı şartların var olması gerekmektedir. Bunlardan ilki, kesin karar alabilme ve yürütebilme yetkisine sahip olmaktır. Özerk kurum, kendisine verilen görevlerle ilgili kararlar alabilmeli ve aldığı kararları uygulayabilmelidir. Bir diğer ifadeyle bu kararlar bir üst organın iznine veya onayına tabi olmamalıdır. İkincisi, kendi organlarını serbestçe kendisi oluşturabilmelidir. Bir diğer ifadeyle kendisi tarafından serbestçe oluşturulan organlar tarafından yönetilmelidir. Üçüncüsü ise kendisine verilen görevlerle orantılı yeterli mali kaynaklara sahip olmalı ve bu kaynakları serbestçe kullanabilmelidir (Demir, 2005, s. 275276, 280; Keleş, 2006, s. 52; Öner, 2006, s. 11; Tortop, 1999, s. 22-23;).

Özerkliğin üç boyutu bulunmaktadır. Bunları; siyasi özerklik, idari özerklik ve mali özerklik şeklinde sınıflandırabiliriz. Özerkliğin, siyasal alanda olması durumunda siyasi özerklikten söz edilir (Sobacı ve Köseoğlu, 2016, s. 18; Ulusoy ve Akdemir, 2009, s. 263). Üniter devletlerde kurumların siyasi özerkliğinden söz edilemez. $\mathrm{Bu}$ nedenle siyasi özerkliğin, çalışmanın konusuyla kesinlikle ilişkisi bulunmamakta ve çalışmanın kapsamı içinde yer almamaktadır. Bu noktada, asıl önemli olan ve üzerinde önemle durulması gereken idari ve mali özerklik kavramlarıdır. Çünkü 1 No'lu Cumhurbaşkanlığı Kararnamesine göre Cumhurbaşkanlığ1 ofislerinin idari ve mali özerkliği bulunmaktadır.

\subsection{1. İdari Özerklik}

İdari (yönetsel) özerklik, esasında idari örgütlenmeye, bir diğer ifadeyle kamu hizmetlerinin yerine getirilmesine ilişkin bir konudur. Süreç içerisinde bazı kamu hizmetlerinin 
merkezi yönetimin dişında, merkezi yönetime danışılmadan veya merkezi yönetimden izin alınmadan yerine getirilmesi bir gereklilik haline gelmiştir. $\mathrm{Bu}$ da idari özerkliğe sahip kurumların ortaya çıkmasını sağlamıştır (Demir, 2005, s. 276; Öner, 2006, s. 10). İdari özerklik, üst bir kamu kuruluşuna bağlı olmakla birlikte, bir kamu kurumunun kanunlarla kendisine verilen görevleri yerine getirebilmek için yine kanunlarla kendisine verilen yetkileri, kendi belirlediği organları vasıtasıyla serbestçe kullanabilme yeteneği şeklinde ifade edilebilir. Daha somut bir ifadeyle bir kamu kurumun yetkili organlarının, kanunlarla kendisine verilen görevleri yerine getirirken, merkezi yönetime danışmadan veya izin almadan kendi başına yürütülebilir kararlar alıp, işlemler yapabilmesi ve bunları uygulayabilme yeteneğidir. İdari özerklik ile merkezi yönetimden, idari özerkliği olan kurumlara, kanunlarla belirlenmiş kamu hizmetlerini daha etkin bir biçimde yerine getirilebilmeleri için yetki aktarımı yapıldığını söyleyebilmek mümkündür. $\mathrm{Bu}$ sebeple idari özerkliğe ilişkin en önemli konulardan birisi, iki kurum arasındaki bağın niteliğidir. Çünkü bağın niteliği, idari özerkliği bulunan kamu kurumunun serbest hareket edebilme yeteneğinin sınırını belirlemektedir. Söz konusu bağın niteliğinin belirlenmesi noktasında da tüzel kişilik devreye girmektedir. İdari özerkliğe sahip kamu kurumunun tüzel kişiliğinin bulunmaması durumunda aradaki bağın niteliği hiyerarşi olarak ortaya çıkmaktadır. Bu durumda gerçek anlamda bir serbestlikten kısacası idari özerklikten söz etmek mümkün değildir. Çünkü bu durumda kamu hizmetleri yine merkezi yönetiminin hiyerarşik yapısı içerisinde gerçekleştirilmektedir. Üst kuruluşlar dilediği zaman, emir ve direktifleriyle müdahale edebilme imkanına sahiptir. Ayrıca yine üst kuruluşlar sahip oldukları hiyerarşik denetim yetkisiyle bu kurumları dilediği gibi yönlendirebilmektedir. Ancak idari özerkliği bulunan kamu kurumunun devlet tüzel kişiliğinin dışında kendisine ait kamu tüzel kişiliğinin bulunması durumunda aradaki bağın niteliği hiyerarşi olmaktan çıkmakta ve idari vesayet ilişkisine dönüşmektedir. İşte bu durumda gerçek anlamda bir serbestlikten söz etmek mümkün olabilmektedir. Zira yukarıda da özerkliğinin tek başına çok anlamlı olmadığı, tüzel kişilik ile bir arada olması durumunda önemli bir hale geldiği ifade edilmişti. Bu durumda üst kuruluş, hiyerarşi ilişkisi olmadığ için doğrudan emir ve direktif verememektedir. Ayrıca alınan bir kararı iptal etme veya değiştirme yetkisi de kanunlarla büyük ölçüde sınırlandırılmaktadır.

İdari özerklikten söz edebilmek için ilk olarak idari özerkliğe sahip kurumların, kendisini yönetecek organlarını seçimle kendileri belirleyebilme yetkisine sahip olmalıdır. İdari özerklik için bu son derece önemli bir koşuldur. Çünkü bu yetki, idari özerkliğinin derecesinin önemli bir göstergesi durumundadır. İdari özerkliğe sahip bir kurumun kendi organlarını kendisinin belirleyebilmesi, idari özerkliğin en üst noktada olduğunu göstermektedir. Organların merkezi yönetim tarafından atanması durumunda ise, idari özerklik kısmen sınırlandırılmış olmakta, ancak bu durum, idari özerkliğin tamamıyla ortadan kalktığı anlamına gelmemektedir. İkinci olarak bu kurumlar, kanunlarla kendilerine verilen konularda kendi organları tarafindan serbestçe karar alıp, bu kararları uygulayabilme hakkına sahip olmalıdır (Öner, 2006, s. 11; Tortop, 1999, s. 22-23;). Bir diğer ifadeyle idari özerkliğe sahip bir kurum, kanunlarla kendisine verilen konularda, bağlı olduğu üst kuruluşa sormadan, onayına ihtiyaç duymadan veya ondan izin almadan karar alıp, uygulayabilmelidir. Elbette ki uygulamada bunun, sınırsız olmadığ herkesçe kabul edilmektedir. Ancak idari özerkliğe sahip bir kurumun aldığı kararların ne kadar azı üst kuruluşun onayına veya iznine tabi olursa, idari özerkliğin derecesinin o kadar yüksek olacağı da bir gerçektir (Demir, 2005, s. 281-282).

İdari özerklik ile denetim arasında çok yakın bir ilişki bulunmaktadır. Çünkü merkezi yönetim tarafından uygulanan denetim, idari özerkliği oldukça sınırlandırabilir, hatta ortadan kaldırabilir. $\mathrm{Bu}$ nedenle merkezi yönetim tarafından uygulanacak idari vesayet denetiminin çerçevesi Anayasa ve yasalarda belirtilen yöntemlerle sınırlıdır ve sadece kanunilik denetimi şeklinde olması gerekmektedir. Bu bağlamda uygulanacak olan idari vesayet denetimi ölçülü olmalı, merkezi yönetimin keyfi davranışlarından uzak tutulmalı ve idari özerkliği zedelemeyecek biçimde gerçekleştirilmelidir (Demir, 2005, s. 278-279, 282; Tortop, 1999, s. 16). Nitekim Avrupa Yerel Yönetimler Özerklik Şartı'nın özellikle üzerinde durduğu konulardan birisi de budur. Türkiye'nin de taraf olduğu bu Şart'a göre idari vesayet denetimi 
ancak anayasa veya kanunla belirlenmiş durumlarda ve yöntemlerle uygulanabilir. İdari vesayet denetimi bazı istisnalar haricinde kanunilik denetimi şeklinde gerçekleştirilir. Daha somut bir ifadeyle idari özerkliğe sahip kurumların kanunlarla kendilerine verilen görev ve yetkiler çerçevesinde hareket edip etmediklerini denetlemeye yöneliktir. İdari özerkliğe sahip kurumlar üzerinde uygulanacak idari vesayet denetiminin amac1, anayasa ve yasalara uygunluğun sağlanmasından ve idarenin bütünlüğü ilkesinin temininden başka bir şey olamaz (m.8).

Türkiye'de, bazı kamu hizmetlerinin merkezi yönetimin dışında ancak onun denetimi altında kamu tüzel kişiliğine sahip, idari özerkliği olan yerinden yönetim kuruluşlarınca yerine getirildiği görülmektedir. Yerinden yönetim kuruluşları, kanunlarla kendilerine verilen kamu hizmetlerinin yerine getirilmesi bakımından serbest hareket edebilme yeteneğine sahiptir. Ancak yerinden yönetim kuruluşlarının tamamının idari özerkliğin bütün koşullarını tam anlamıyla sağlayabildiklerini söylemek pek mümkün değildir. Yerinden yönetim kuruluşları içinde yer alan yerel yönetimlerin, idari özerkliğin her iki koşulunu da büyük ölçüde gerçekleştirebildikleri görülmektedir. Anayasaya göre yerel yönetimlerin karar organları, kanunda gösterilen seçmenleri tarafindan seçilerek oluşturulur (md. 127/1). Dolayısıyla yerel yönetimler, organlarını belirleme konusunda serbest hareket edebilmektedirler. Ayrıca yine kanunlarla kendilerine verilen kamu hizmetlerini yerine getirirken merkezi yönetimin müdahalesi olmadan belirli ölçülerde serbestçe karar alıp uygulayabilmektedirler. Fakat fonksiyonel yerinden yönetim kuruluşlarında ise koşulların karşılanması açısından farklılıklar bulunmaktadır. Örneğin kamu kurumu niteliğindeki meslek kuruluşları idari özerkliğin her iki koşulunu da sağlamakta, kendi organlarını belirlemede serbest hareket edebildikleri gibi, kendi organları vasıtasıyla karar alıp, bu kararları uygulayabilmektedirler. Ancak TRT, Kİ'ler, Üniversiteler gibi fonksiyonel yerinden yönetim kuruluşlarının ise idari özerkliğin ikinci koşulunu sağlamakla birlikte ilk koşulu olan kendisini yönetecek organları belirleyebilme noktasında serbest hareket edemedikleri görülmektedir (2547 sayılı Yükseköğretim Kanunu; 233 sayılı KHK, 3 nolu Cumhurbaşkanlığı Kararnamesi).

\subsubsection{Mali Özerklik}

Mali özerklik, idari özerkliği olan kurumların kendilerine verilen görev ve sorumlulukları yerine getirebilmeleri için gelir kaynaklarına sahip olabilmeleri ve kanuni koşullara uygun olmak şartıyla harcama yapabilmeleri şeklinde tanımlanabilmektedir. Mali özerklik, merkezi yönetimin müdahalesi olmaksızın kendi öz gelirlerini oluşturabilme, öz gelirlerinin oranını tespit edebilme, gerektiğinde gelirlerini yükseltebilme ve harcama ile harcama önceliklerini belirleyebilme yetkisi şeklinde de tanımlanabilmektedir. Mali özerkliğin gelir kaynaklarını, bunların sınırlarını ve miktarını serbestçe belirleyebilme yetkisini de içerdiği görülmektedir. Mali özerklik aynı zamanda özerk kuruluşların kendi bütçelerini merkezi yönetimin dışında serbestçe oluşturabilmesi ve yasal sınırlara uygun olmak şartıyla borçlanabilmesi anlamına da gelmektedir (Ulusoy ve Akdemir, 2009, s. 263-264). Kamu kurumlarının kendisine ait bütçelerini kendilerinin yönetebilmesi, kanunlara uygun olmak koşuluyla bütçelerindeki gelirlerini ve giderlerini belirleyebilme konusunda serbest hareket edebilmeleri şeklinde tanımlanmaktadır.

Mali özerklik, özerk kurumlara, kanunlarla verilen görevlerini yerine getirebilmeleri için gerekli olan mali kaynăg sağlamanın yanı sıra, aynı zamanda varlığını devam ettirebilme imkanı vermektedir. Aksi durumda özerk kurumlar görevlerini yerine getirmekte güçlük çekeceği gibi merkezi yönetim tarafından aktarılacak kaynaklara bağımlı olmaları durumu ortaya çıkacaktır. Bu durum, özerk kurumların kendi organları aracılığıyla serbestçe karar alma ve bu kararları uygulayabilme yeteneklerini, bir diğer ifadeyle idari özerkliğini büyük ölçüde sinırlandıracaktır. O halde özerk bir yönetimden söz edebilmesi için sadece idari özerkliğin yeterli olmadığı ortadadır. Dolayısıyla mali özerkliğin, idari özerkliğin bir tamamlayıcısı olduğu, birlikte bir bütünü oluşturdukları görülmektedir (Ulusoy ve Akdemir, 2009, s. 264-265; Yontar ve Özer, 2018, s. 102-103). 
Bilindiği üzere kamu tüzel kişiliğine sahip olan kamu kurumlarının, merkezi yönetimin bütçesi dışında ayrı bir bütçesi bulunmaktadır. Ancak bütçenin varlığı tek başına çok anlamlı değildir. Çünkü bütçenizdeki parayı hiçbir müdahale olmaksızın kendiniz yönetemiyorsanız, bütçenizin olmasının da bir önemi yoktur. Bu nedenle bütçenizin var olmasının yanı sıra bütçenizi yönetebilme hakkınızın da var olması gerekmektedir. Böylelikle bütçenizi kanunlara uygun olmak şartıyla, hiçbir müdahale olmaksızın kendiniz yönetebilir, kanunlarla size verilen görevlerin etkin bir biçimde yerine getirilebilmesi için serbest bir biçimde harcayabilirsiniz.

\section{Cumhurbaşkanlığı Ofislerine İlişkin Değerlendirme}

Yukarıdaki açıklamalar çerçevesinde Cumhurbaşkanlığı ofislerinin yapısını değerlendirmek çok daha kolay olacaktır. Cumhurbaşkanlığı ofislerine ilişkin değerlendirmeyi üç alt başlıkta toplamak mümkündür. Bunlardan ilki Cumhurbaşkanlığı ofislerinin Türk idare teşkilatı içerisindeki yeri, ikincisi Cumhurbaşkanı ile Cumhurbaşkanı ofisleri arasındaki ilişki ve son olarak üçüncüsü de Cumhurbaşkanlığ 1 ofislerinin denetlenmesidir.

\subsection{Cumhurbaşkanlığı Ofislerinin Türk İdare Teşkilatındaki Yeri}

Cumhurbaşkanlığı ofisleri açısından burada tartışılması gereken ilk konu Cumhurbaşkanlığ 1 ofislerinin Türk idare teşkilatındaki yeridir. Peki, Cumhurbaşkanlığı ofissleri mevcut yapısıyla Türk idare teşkilatı içerisinde nerede yer almalıdır?

İdare hukukunda devlet tüzel kişisiyle merkezi yönetimin bir diğer ifadeyle merkezi yönetim içerisinde yer alan başkent ile taşra örgütlerinin tamamının kastedildiği ve devlet tüzel kişiliğinin tek ve bir bütün olduğu görülmektedir. Bu nedenle merkezi yönetim içerisinde yer alan örgütlerin tamamının devlet tüzel kişiliğini kullandığı kabul edilmektedir. Merkezi yönetim içerisinde yer alan bir örgütün, devlet tüzel kişiliğinin haricinde ayrı bir tüzel kişiliğe sahip olabilmesi, üstü konumunda olan idarelerden serbest bir biçimde karar alma ve yürütme yetkisinin bulunabilmesi ve yine genel idare bütçesinin dıșında kendisine ait özel bir bütçesinin olabilmesi idare hukuku ilkeleri gereğince pek mümkün değildir. Merkezi yönetimin gerek başkent teşkilatında yer alan Cumhurbaşkanlığı, bakanlıklar gibi kurumlar ile gerekse taşra teşkilatında yer alan il ve ilçe örgütlerinin kendilerine ait tüzel kişiliklerinin bulunmaması ve tamamının devlet tüzel kişiliğini kullanıyor olması, ayrıca idari ve mali açıdan serbest hareket edebilme yeteneklerinin bulunmaması ve bütçelerinin genel idare bütçesine tabi olması bu durumun çok açık bir ispatı niteliğindedir.

Kamu tüzel kişiliği ile idari ve mali özerklik yerinden yönetim kuruluşu olmanın en temel şartları arasında sayılmaktadır (Gözler, 2003, s. 122; Gözübüyük, 2003, s. 38; Kalabalık, 2008, s. 39). Bir diğer ifadeyle devlet tüzel kişiliğinin dışında ayrı bir kamu tüzel kişiliği ile serbest hareket edebilme yeteneği olmayan bir kuruluşun yerinden yönetim kuruluşu olarak nitelendirilmesi mümkün değildir. Esasında merkezi yönetim kuruluşları ile yerinden yönetim kuruluşlarını birbirinden ayıran en temel kriterlerin bu olduğunu söylemek mümkündür. Örneğin il ve ilçe teşkilatı, yerelde örgütlenmiş olmakla birlikte, devlet tüzel kişiliğinin dışında ayrı bir kamu tüzel kişiliğine sahip olmadığı ve başkent teşkilatının emir, talimat ve yönlendirmesinin dışında serbest hareket edebilme yeteneği bulunmadığ 1 için yerinden yönetim kuruluşu değillerdir (Gözler, 2018, s. 38-39). Öyleyse devlet tüzel kişiliği dışında kendisine ait kamu tüzel kişiliği bulunan, idari ve mali konularda kanunlara uygun olmak kaydıyla serbest hareket edebilme yeteneğine sahip olan kuruluşların da merkezi yönetim kuruluşu olarak nitelendirilmesi mümkün değildir. O halde kendisine haiz kamu tüzel kişiliği ile idari ve mali özerkliği bulunan kuruluşların merkezi yönetim içerisinde değil tam tersine yerinden yönetim içerisinde yer alması gerekmektedir.

$\mathrm{Bu}$ açıklamalardan hareketle, 1 No'lu Cumhurbaşkanlığı Kararnamesinin 525. maddesine göre devlet tüzel kişiliğinin dışında ayrı bir kamu tüzel kişisi olarak düzenlenen, idari ve mali özerkliği bulunan ve kendisine ait özel bütçesi olan Cumhurbaşkanlığı ofislerinin, merkezi yönetimin içinde yer alabilmesi idare hukuku ilkeleri bakımından pek mümkün 
görünmemektedir. $\mathrm{O}$ halde merkezi yönetim teşkilatı içinde yer alması mümkün olmayan Cumhurbaşkanlığı ofislerinin mevcut yapısı nedeniyle bir yerinden yönetim kurumu gibi göründüğü sonucuna ulaşılmaktadır.

Bilindiği üzere yerinden yönetim coğrafi ve fonksiyonel yerinden yönetim olmak üzere ikiye ayrılmaktadır. Cumhurbaşkanlığı ofislerinin hangi yerinden yönetim kuruluşlarına daha fazla benzediği sorusu akla gelmektedir. Bu soruyu yanıtlamadan önce ilk olarak coğrafi yerinden yönetim ve fonksiyonel yerinden yönetim kuruluşlarına kısaca bakmak da yarar vardır.

Yerel yönetimler veya mahalli idareler olarak da adlandırılan coğrafi yerinden yönetim kuruluşları, belirli bir coğrafi alanda bir arada yaşanan insanların ortak ihtiyaçlarını karşılamak amacıyla örgütlenmesiyle ortaya çıkmışlardır (Gözler, 2018, s. 39). Dolayısıyla coğrafi yerinden yönetim kuruluşları kişi topluluğundan (kamu idaresi) meydana gelmektedir (Gözler, 2003, s. 133). Yerel yönetim kuruluşlarının coğrafi sınırları içinde kanunlarla kendisine verilen birçok yerel nitelikli kamu hizmetini yerine getirmekle yükümlü olduğu görülmektedir. Bu bakımdan yerel yönetim kuruluşlarının yetkilerinin coğrafi alanla sınırlandırıldığını, özerkliğin ise bir coğrafi alana verildiğini söylemek mümkündür (Şengül, 2010, s. 9). Anayasamızda "mahalli idareler; il, belediye veya köy halkının mahalli müşterek ihtiyaçlarını karşılamak üzere kuruluş esasları kanunla belirtilen ve karar organları, gene kanunda gösterilen, seçmenler tarafindan seçilerek oluşturulan kamu tüzelkişileridir" şeklinde tanımlanmaktadır (1982 Anayasası, md. 127/1). Anayasa, yerel yönetim kuruluşlarını il (il özel idaresi), belediye ve köy şeklinde doğrudan tanımlama yolunu seçmiştir. Anayasanın benimsemiş olduğu bu yöntem, bir taraftan yerel yönetim kuruluşlarını güvence altına alırken, diğer taraftan da yerel yönetim kuruluşlarını sınırlandırmaktadır. Çünkü anayasa değişikliği olmadan Türkiye'deki yerel yönetim kuruluşlarının arttırılması veya azaltılması şu durumda mümkün değildir.

Yerinden yönetimin diğer ayağını ise fonksiyonel yerinden yönetim kuruluşları oluşturmaktadır. Süreç içerisinde bazı kamu hizmetlerinin niteliği gereği merkezi yönetiminin dışındaki örgütler tarafindan yerine getirilmesinin daha doğru olacağı düşüncesi benimsenmiştir. Çünkü devletin üstlendiği bazı kamu hizmetleri özel teknik, bilgi ve uzmanlık gerektirmektedir. $\mathrm{Bu}$ nitelikteki kamu hizmetlerinin etkin ve verimli bir biçimde merkezi yönetim tarafından yerine getirilmesi pek olanaklı değildir. Bu amaçla merkezi yönetimin dışında örgütlenmiş ve kendisine verilen kamu hizmetini yerine getirmekle yükümlü, kamu tüzel kişiliğine haiz, idari ve mali özerkliği bulunan, kendisine ait bütçesi olan kuruluşlar oluşturulmuştur. Bunlara fonksiyonel yerinden yönetim kuruluşları adı verilmektedir (Gözler, 2018, s. 39; Gözübüyük, 2003, s. 38). Fonksiyonel yerinden yönetim kuruluşlarının hangilerinin olduğu anayasa tarafından doğrudan belirtilmemiştir. Bu nedenle anayasamıza göre bu tür kamu tüzel kişileri, kanunla ve Cumhurbaşkanlığı kararnamesi ile doğrudan kurulabilmektedir (1982 Anayasası, md. 123). Fonksiyonel yerinden yönetim kuruluşlarının mal topluluğu (kamu kurumu) şeklinde kurulduğu (Gözler, 2003, s. 133-134) ve kuruluşunu sağlayan tek bir kamu hizmetini yerine getirmekle görevli oldukları, özerkliğin bir kamu hizmetine verildiği görülmektedir. Fonksiyonel yerinden yönetim kuruluşları, kuruluşunu sağlayan kamu hizmeti ile sınırlandırılmıştır (Şengül, 2010, s. 9). Bir diğer ifadeyle kendisine verilen kamu hizmetini herhangi bir coğrafi sınırlandırma olmaksızın Türkiye'nin her yerinde yerine getirebilmektedir. Yerel yönetim kuruluşlarıyla aralarındaki en önemli farklardan birisi de budur.

Cumhurbaşkanlığı ofisleri ele alındığında ve değerlendirildiğinde; ilk olarak Cumhurbaşkanlığı ofislerinin anayasa düzenlemesiyle değil, Cumhurbaşkanlığı kararnamesiyle kuruldukları görülmektedir. O halde anayasanın 127. maddesinde sayılan mahalli idare kuruluşlarından olmadı ̆ 1 son derece açıktır. Ayrıca yine anayasanın 127. maddesine dayanılarak oluşturulmuş kuruluşlardan da değildir. Çünkü 11/02/2017 tarihli 29976 sayılı R.G.'de yayımlanan “Türkiye Cumhuriyeti Anayasasında Değişiklik Yapılmasına Dair Kanun” incelendiğinde anayasanın 127. maddesinde sadece mahalli idarelerin seçim dönemine ilişkin düzenleme yapıldığı görülmektedir. İkincisi Cumhurbaşkanlığ 1 ofislerinin temel unsurunun kişi topluluğu değil, mal ve kamu hizmeti unsuru olduğu görülmektedir. Bir diğer ifadeyle ofislerin, 
kamu idaresi değil, kamu kurumu olarak nitelendirilmesi gerekmektedir. Üçüncüsü Cumhurbaşkanlığı ofislerinin kendisine verilen birçok görevi belirli bir coğrafi alan içinde yerine getiren bir kuruluş değil, kendisine verilen görevleri tüm Türkiye'de yerine getiren, tek bir kamu hizmeti ile sınırlandırılmış bir kuruluş olduğu görülmektedir. Son olarak da ofislerin organları seçim usulüyle değil, doğrudan atama usulüyle belirlenmektedir. Bütün bu değerlendirmeler neticesinde Cumhurbaşkanlığı ofislerinin yukarıda coğrafi yerinden yönetim kuruluşları için ifade edilen özelliklerle örtüşmediği sonucuna varılmaktadır. Bununla birlikte Cumhurbaşkanlığı ofislerinin kuruluşu, yapısı ve işleyişiyle fonksiyonel yerinden yönetim kuruluşlarıyla büyük ölçüde örtüştükleri görülmektedir.

\subsection{Cumhurbaşkanı İle Cumhurbaşkanlığı Ofissleri Arasındaki İliş̧ki}

Tartışmalara neden olan konulardan birisi de Cumhurbaşkanı ile ofisler arasındaki ilişkinin boyutudur. Cumhurbaşkanı ile ofisler arasında iki tür ilişkinin olabilmesi imkanı vardır. Bunlardan birincisi, aynı tüzel kişilik içerisinde yer alan kurumlar arasında gerçekleşen hiyerarşi ilişkisidir. Hiyerarşi ilişkisi için kurumların aynı tüzel kişi içinde yer alması gerekmektedir. İkincisi de farklı tüzel kişiler arasında gerçekleşen idari vesayet ilişkisidir. Bilindiği üzere ayrı tüzel kişilik içerisinde yer alan kurumlar, aynı hiyerarşi zinciri içinde bulunmadığ 1 ve aralarında ast-üst şeklinde bir yapılanma olmadığı için hiyerarşi ilişkisinin bulunması söz konusu değildir. $\mathrm{Bu}$ nedenle bu tür kurumlar arasında idari vesayet şeklinde sınırlı bir ilişki kurulmaktadır.

Cumhurbaşkanı merkezi yönetimin başkent teşkilatı içerisinde yer almaktadır. Bu nedenle devlet tüzel kişiliğine tabidir. Cumhurbaşkanı devlet tüzel kişiliğinin en tepesinde ve onu temsil etmekle görevlidir. Merkezi yönetimin içinde yer alan ve devlet tüzel kişiliğine tabi olan diğer bütün kurumlarla arasında ast-üst şeklinde bir yapılanma vardır. Doğal olarak da bu kurumlarla aralarında hiyerarşi ilişkisi söz konusudur. Bir diğer ifadeyle Cumhurbaşkanı, merkezi yönetimin içinde ve devlet tüzel kişiliğine tabi bütün kurumların hiyerarşik amiri konumundadır. Dolayısıyla bütün bu kurumlara doğrudan emir ve direktif verebilir, onların işlemleri üzerinde geniş bir söz sahibidir.

Cumhurbaşkanlığı ofisleri ise 1 No'lu Cumhurbaşkanlığı Kararnamesi ile Cumhurbaşkanlığı teşkilatı içerisinde kurulmuştur. Yukarıda da ifade edildiği üzere her ne kadar merkezi yönetimin içerisinde düzenlenmeye çalışılmış olsa da, yine 1 No'lu Cumhurbaşkanlığ 1 Kararnamesiyle devlet tüzel kişiliğinin dışında kendisine kamu tüzel kişiliği verilmiştir. Bir diğer ifadeyle devlet tüzel kişiliğinin hiyerarşik yapısı içinde değil dışında olduğu açıkça ifade edilmiştir. Bununla birlikte yine 1 No'lu Cumhurbaşkanlığ 1 Kararnamesinde ofislerin, kendisine ait tüzel kişiliğinin yanı sıra, idari ve mali anlamda özerkliğe sahip oldukları ifade edilmektedir. Yani her ne kadar bir üst kuruluşa bağlı olsa da, kanunla kendisine verilen kamu hizmetlerinin yerine getirilmesi noktasında ve bu hizmetleri yerine getirirken gerekli olan mali konuları düzenleyebilme hususunda serbestliğe sahiptir.

$\mathrm{Bu}$ açıklamalardan Cumhurbaşkanı ile Cumhurbaşkanlığı ofislerinin ayrı tüzel kişilikler içinde yer aldıkları sonucuna ulaşılmaktadır. O halde idare hukuku bakımından aralarında astüst şeklinde bir yapılanmanın olabilmesi ve aynı hiyerarşi zincirinde bulunabilmeleri şu durumda pek mümkün görünmemektedir. Bir diğer ifadeyle iki ayrı tüzel kişilik söz konusu olduğu için Cumhurbaşkanı ile ofislerin aralarında hiyerarşi ilişkisinin var olabilmesi idare hukuku öğretisi çerçevesinde mümkün değildir. $O$ halde Cumhurbaşkanının doğrudan yönlendirme, emir ve talimat verme yetkisinden de söz etmek pek mümkün görünmemektedir. Ayrıca sahip olduğu idari ve mali özerklik, kanunlarla kendisine verilen görevleri yerine getirirken ve bu amaçla verilen bütçeyi kullanırken serbest hareket edebilme yeteneği vermektedir. Kanunlara uygun olmak kaydiyla gerek idari gerekse mali konularda merkezi yönetime yani Cumhurbaşkanına danışmadan karar alıp, bunları yürütebilme yeteneğine sahip olduğu görülmektedir. Bu durumda Cumhurbaşkanı ile ofisler arasında idare hukuku öğretisi gereği hiyerarşi ilişkisi değil, idari vesayet ilişkisinin olması gerekmektedir. Teorik açıdan böyle bir sonuca ulaşılmakla birlikte uygulamada farklı bir durumun olduğunu söylemek mümkündür. 
Çünkü 1 No'lu Cumhurbaşkanlığı Kararnamesinin 533. maddesinde Cumhurbaşkanı ile ofisler arasındaki ilişki doğrudan düzenlenmiş ve Cumhurbaşkanının, ofiste görev yapan her kademedeki yöneticiye yapmakla yükümlü olduğu görev ve hizmetleri yerine getirirken emir ve direktif verebileceği ifade edilmiştir (Üstün, 2019, s. 33). Kararnamede bir taraftan cumhurbaşkanı ile ofisler ayrı tüzel kişilikler içinde düzenlerken diğer taraftan da aynı tüzel kişilik içinde gibi hiyerarşik bir bağ kurulmaktadır. Dolayısıyla 1 No'lu Cumhurbaşkanlığ 1 Kararnamesinin ofislerin yapısına ilişkin bölümünde kendi içinde de çelişkilerin olduğunu söylemek mümkündür.

Yukarıda ofislerin kuruluş gerekçesinde de açıkça ifade edildiği üzere Cumhurbaşkanlığı ofisleri, Cumhurbaşkanının görevlerini yerine getirmesinde yardımcı olan kurmay-yardımcı bir birim olarak kurulmuştur. Bu bakımdan Cumhurbaşkanı ile yakın bir işbirliği içinde çalışmaları gerektiği de muhakkaktır. Cumhurbaşkanına yardımcı olmak amacıyla kurulmuş bir kuruma Cumhurbaşkanının doğrudan emir ve talimat verebilmesi, işlemleri üzerinde her türlü yetkiye sahip olması da son derece doğal bir durumdur. Ancak bu durumun, ofislerin mevcut yapısı ile ters düştüğü ve bazı tartışmalara sebep olduğu da bir gerçektir. $\mathrm{Bu}$ nedenle Cumhurbaşkanı ile ofisler arasındaki ilişkinin idari vesayet ilişkisi şeklinde sınırlı bir ilişki şeklinde gerçekleştirilmesi yerine, ofislerin kamu tüzel kişiliği ile idari ve mali özerkliğinin kaldırılarak aradaki ilişkinin idare hukuku öğretisine uygun bir biçimde hiyerarşi ilişkisi şeklinde olmasının çok daha doğru olacağını söylemek gerekmektedir. Böylelikle ofislerin kuruluş amacına uygun bir yapıya kavuşturulmaları da sağlanmış olacaktır. Aksi durumda kuruluş amacı ile uyuşmayan bir kamu kurumu ile karşı karşıya kalınması söz konusu olacaktır.

\subsection{Cumhurbașkanı Ofislerinin Denetimi}

Anayasanın 123. maddesinde ifade edilen idarenin bütünlüğü ilkesini sağlamak için geliştirilmiş iki tür idari denetim bulunmaktadır. Bunlar hiyerarşi ve idari vesayet denetimidir. Hiyerarşi denetimi kural olarak aralarında hiyerarşi ilişkisi bulunun, ast-üst biçiminde örgütlenen kurumlar veya kamu görevlileri arasında gerçekleşen denetimdir (Aykaç ve Özer, 2002, s. 8; Coşkun, 2002, s. 85). Hiyerarşi iliş̧kisi aynı tüzel kişi veya aynı idare içinde yer alan kurumlar ya da kamu görevlilerinin ast-üst biçimindeki örgütlenmesiyle ortaya çıkmaktadır (Gözler, 2003, s. 169-170). İdari vesayet denetimi ise ayrı tüzel kişiler bir diğer ifadeyle aralarında hiyerarşi ilişkisi bulunmayan kurumlar arasındaki bir idari denetim türüdür. Daha doğru bir ifadeyle idari vesayet denetimi, bazı istisnaları olmakla birlikte, devlet tüzel kişisi olarak ifade edilen merkezi yönetiminin kendi tüzel kişiliğinin dışında ayrı kamu tüzel kişiliğine sahip yerinden yönetim kuruluşlarını denetleme biçimidir (Gözübüyük ve Tan, 2001, s. 932933; Tortop, 1999, s. 13).

Bir kamu kurumuna hangi idari denetim türünün uygulanacağını belirlemede kullanılacak temel kriter, o kurumun kamu tüzel kişiliğine sahip olup olmamasıdır. Çünkü bu bize, o kurumun bir ast-üst ilişkisine tabi olup olmadığını, bir diğer ifadeyle kurumun Türk idare teşkilatı içerisinde tabi olduğu hiyerarşik bir üstünün bulunup bulunmadığını göstermektedir. Eğer bir kurum, Türk idare teşkilatı içerisinde, hiyerarşi zincirinin bir halkası konumunda ise o takdirde hiyerarşik denetime tabidir. Bu durumda o kurum üzerinde hiyerarşi denetimi uygulanabilir. Eğer bir kurum, Türk idare teşkilatı içerisinde, hiyerarşi zincirinin bir halkası durumunda değil ise bu durumda hiyerarşik üstünün olmadığı ortaya çıkmaktadır. Hiyerarşik denetimin uygulanamadığı yerlerde ise idari vesayet denetimi gerçekleştirilmektedir.

1 No’lu Cumhurbaşkanlığı Kararnamesi ile kurulan Cumhurbaşkanlığı ofislerinin Cumhurbaşkanına görevlerini yerine getirmede yardımcı olmak amacıyla kurulmuş kurmayyardımcı bir birim olduğu daha önce de ifade edilmiştir. Dolayısıyla ofislerin Cumhurbaşkanı ile yakın bir ilişki içinde faaliyetlerini yerine getireceği düşünülebilir. Böyle bir durumda da doğal olarak ilk akla gelen denetim türü tabi ki de hiyerarşik denetim olmaktadır. Ancak Cumhurbaşkanlığı ofislerinin yapısı dikkate alındığında, Cumhurbaşkanlığı ofislerine her ne 
kadar merkezi yönetimin başkent teşkilatı içerisinde yer verilmiş olsa da, devlet tüzel kişiliğine dahil olmadığı, aksine merkezi yönetimin tüzel kişiliği dışında kendisine ait bir kamu tüzel kişiliğine sahip olduğu görülmektedir. Bir diğer ifadeyle Cumhurbaşkanı ile Cumhurbaşkanlığı ofisleri ele alındığında iki ayrı tüzel kişiliğin söz konusu olduğu görülmektedir. Hal böyle olunca idare hukuku öğretisine göre Cumhurbaşkanı ile Cumhurbaşkanlığı ofisleri arasında bu haliyle hiyerarşi ilişkininin söz konusu olamayacağı sonucuna ulaşılmaktadır. Bu durumda aralarında hiyerarşi ilişkisi bulunmayan Cumhurbaşkanı ile Cumhurbaşkanlığ 1 ofisleri arasında hiyerarşik denetimin gerçekleşebilmesi pek mümkün görünmemektedir. Cumhurbaşkanlığ 1 ofisleri üzerinde hiyerarşik denetim gerçekleştirilemediğine göre, o halde Cumhurbaşkanlığ ofisleri üzerinde uygulanabilecek idari denetim türünün idari vesayet denetimi olabileceğini söylemek mümkündür. Üstelik Cumhurbaşkanlığı ofislerinin idari ve mali özerkliğe sahip olduğu da göz önüne alındığında, ofislere yönelik uygulanacak denetimin idari ve mali özerkliği zedelemeyecek derecede ölçülülük ilkesi çerçevesinde olması gerekmektedir.

Ancak uygulamada durum farklıdır. Çünkü az önce de ifade edildiği üzere 1 No'lu Kararnamenin 533. maddesiyle Cumhurbaşkanı ile ofisler arasında hiyerarşik bir ilişki kurulmaktadır. Kararnameyle kurulan hiyerarşi ilişkisi, doğal olarak ofisler üzerinde hiyerarşik denetim imkanı da vermektedir. Esasen olması gerekenin, ofislerin kuruluş amacı ve idare hukuku öğretisiyle örtüşenin de bu olduğunu söylemek gerekmektedir. Pratikteki uygulamanın teoriyle uyumlu bir hale getirilebilmesi için ofislerin, devlet tüzel kişiliği içinde yer almasının daha doğru olacağını söylemek mümkündür.

\section{Sonuç ve Öneriler}

2018 yılında yayımlanan 1 No'lu Cumhurbaşkanlığ 1 Kararnamesiyle kurulan Cumhurbaşkanlığı ofislerine ilişkin tartışmaların önemli bir temelinin olduğu görülmektedir. Gerçekten de Cumhurbaşkanlığı ofislerinin yapısal sorunlarının olduğu aşikardır. Sorunun kaynağında, merkezi yönetimin başkent yönetiminde Cumhurbaşkanlığı teşkilatı içerisinde Cumhurbaşkanının görevlerini yerine getirmede kurmay-yardımcı bir birim olarak hayata geçirilen ofislere, aynı kararnameyle kamu tüzel kişiliği ile idari ve mali özerkliğin verilmiş olması yer almaktadır. Bu durum, bir taraftan idare hukuku öğretisi ile önemli ölçüde çelişirken, diğer taraftan da Cumhurbaşkanı ile ofisler arasındaki ilişkinin boyutu, ofislerin Türk idare teşkilatı içerisindeki yerinin neresi olması gerektiği ve ofislerin denetiminin nasıl gerçekleştirileceği gibi birçok soruna yol açmaktadır.

Cumhurbaşkanlığı ofislerinin mevcut yapısıyla merkezi yönetimin başkent yönetiminde Cumhurbaşkanlığı teşkilatı içinde yer almasının sorunlu olduğu sonucuna ulaşılmaktadır. Mevcut haliyle Türk idare teşkilatındaki yerinin, yerinden yönetim kuruluşları altında fonksiyonel yerinden yönetim kuruluşları arasında olmasının daha doğru olacağı görülmektedir. Ancak bu durumda da Cumhurbaşkanı ile aralarındaki ilişkinin hiyerarşi ilişkisi değil, idari vesayet ilişkisi olması gerekmektedir. Buna bağlı olarak da ofislere yönelik olarak uygulanacak denetimin de hiyerarşik denetim değil, idari vesayet denetimi olması gerekmektedir. Fakat bu durumda da Cumhurbaşkanlığ ofislerinin kuruluş düşüncesi ve amaciyla örtüşmeyen son derece farklı bir kurum görüntüsü ortaya çıkmaktadır. Bir diğer ifadeyle Cumhurbaşkanına yardımcı bir birim olmaktan uzaklaşmaktadır.

Cumhurbaşkanlığı ofislerinin kuruluş amacının çok daha önemli ve kayda değer olduğu, ofislerin asıl amacının Cumhurbaşkanının görevlerini yerine getirmesine yardımcı olmak olduğu son derece açıktır. Bu nedenle de Cumhurbaşkanlığ 1 ofislerinin Cumhurbaşkanı ile son derece yakın bir biçimde çalışması, Cumhurbaşkanının emir ve direktifleri doğrultusunda hareket etmesi, görevlerini yerine getirmesi bakımından Cumhurbaşkanına karşı sorumlu olması ve Cumhurbaşkanının hiyerarşik denetimi altında bulunması gerekmektedir. Ancak diğer taraftan da idare hukukunun genel öğretisiyle çelişmemesi ve bu anlamda yeni sorunlara yol açmaması da son derece önemlidir. $\mathrm{Bu}$ sebeple Cumhurbaşkanlığı ofislerini düzenleyen 1 No'lu Cumhurbaşkanlığı Kararnamesinin 525. maddesinin yeniden gözden geçirilerek, ilgili maddede 
yer alan kamu tüzel kişiliği, özel bütçe ile idari ve mali özerklik ifadelerinin metinden çıkarılmasının en doğru yöntem olduğu ve bu değişiklikle Cumhurbaşkanlığı ofislerine ilişkin bütün bu sorunların ve tartışmaların ortadan kaldırılabilmesinin mümkün olduğu söylenebilir.

Çalışmanın kapsamı içerisinde yer verilmemekle birlikte sonraki benzer çalışmalara zemin oluşturması bakımından son olarak merkezi yönetimin başkent örgütü içinde yer verilen Cumhurbaşkanlığ 1 ofislerine hangi gerekçeyle kamu tüzel kişiliği ile idari ve mali özerkliğin verilmiş olabileceğini de burada kısaca tartışmak da yarar vardır. Yeni hükümet sisteminde Cumhurbaşkanlığı ofisleri, kamu politikalarının oluşturulması ve uygulanmasının takibi konusunda Cumhurbaşkanına yardımcı olmakla görevli esas yetkili iki birimden birisidir. Bu çerçevede 1 No'lu Cumhurbaşkanlığı Kararnamesiyle hem politika kurullarına hem de Cumhurbaşkanlığı ofislerine proje geliştirme, politika alternatifleri üretme, saha çalışmaları yapma, aktörler arası işbirliği faaliyetlerini gerçekleştirme, veri toplama, analiz etme ve politika uygulamalarına ilişkin raporlama gibi birçok görev ve yetki verildiği görülmektedir. Politika kurullarının, isminden de anlaşılacağı üzere, bir kurul şeklinde planlandığı ve bu haliyle bir teşkilata sahip olmadığı gibi görevlerini yerine getirmesini sağlayacak kendisine ait personelinin dahi bulunmadığ 1 , kurulun sekretarya işlemlerinin dahi Cumhurbaşkanlığ idari işler başkanlığ 1 tarafından gerçekleştirildiği 1 No'lu Cumhurbaşkanlığ 1 Kararnamesinden açıkça anlaşılmaktadır. $\mathrm{Bu}$ anlamda politika kurullarının daha ziyade kurmay bir birim şeklinde düşünüldüğünü söyleyebilmek mümkündür. Cumhurbaşkanlığı ofisleri ise kendisine ait bir teşkilatı ve personeli bulunan bir kamu kurumu şeklinde kurulmuştur. Dolayısıyla 1 No'lu Cumhurbaşkanlığı Kararnamesiyle politika kurulları ile ofislere verilen kamu politikasına ilişkin görev ve yetkilerin esas itibarıyla ayrı bir teşkilatı ve personeli bulunan ofisler tarafından yerine getirilmesi gerektiği söylenebilir. İşte bu noktada ofislerin kendisine verilen görevleri çok daha etkin bir biçimde yerine getirebilmesi, görevlerini yerine getirirken merkezi yönetiminin bazen güç işleyen bürokrasisine takılmaması, kendisine verilen yetkileri gerektiğinde merkezi yönetime danışmadan hızlı bir biçimde kullanabilmesi, icracı nitelikte kararlar alabilmesi ve bütün bunları yürütebilmesi için gerekli olan mali kaynağa kolaylıkla ulaşabilmesi için kamu tüzel kişiliği ile idari ve mali özerkliğin verilmiş olabileceğini söylemek mümkündür. Zira günümüzde kamu hizmetlerinin etkin bir biçimde yerine getirilmesi bakımından kamu politikalarının doğru ve sonuç odaklı olarak oluşturulmasının son derece hayati bir öneme sahip olduğu birçok kesim tarafından kabul edilmektedir.

\section{Kaynakça}

Akman, E. (2019). Cumhurbaşkanlığı hükümet sisteminde kamu politikası aktörleri. PRADOKS Ekonomi, Sosyoloji ve Politika Dergisi, 15 (1), 35-54.

Akyılmaz, B., Sezginer, M. ve Kaya, C. (2018). Türk idare hukuku. 9. Baskı. Ankara: Savaş Yayınları.

Angın, C. (2016). Anayasa Mahkemesi ve Danıştay kararlarında yerel yönetimler ve yerel özerklik. ODÜ Sosyal Bilimler Araştırmaları Dergisi, 6(3), 643-656.

Avrupa Yerel Yönetimler Özerklik Şartı (1985). R.G. Tarihi: 03/10/1992. R.G. Sayısı: 21364.

Aykaç, B. ve Özer, M. A. (2002). Mahalli idarelerin denetiminde etkinlik arayışları. Yerel Yönetim ve Denetim Dergisi, 7 (4), 3-25.

Coşkun, B. (2002). Türk kamu yönetiminde idari denetim süreci ve bu süreç içinde ortaya çıkan sorunlar. Türk İdare Dergisi, Y11: 74 (437), 81-104.

Cumhurbaşkanlığı Teşkilatı Hakkında Cumhurbaşkanlığı Kararnamesi. Kararname No: 1. R.G. Tarihi: 10/07/2018. R.G. Sayıs1: 30474.

Cumhurbaşkanlığı Teşkilatı Hakkında Cumhurbaşkanlığı Kararnamesi. Kararname No: 3. R.G. Tarihi: 10/07/2018. R.G. Sayıs1: 30474. 
Cumhurbaşkanlığg Teşkilatı Hakkında Cumhurbaşkanlığı Kararnamesinde Değişiklik Yapılmasına Dair Cumhurbaşkanlığı Kararnamesi. Kararname No: 48. R.G. Tarihi: 24/10/2019. R.G. Tarihi: 30928.

Çağlayan, R. (2016). Kamu tüzel kişiliği kavramı ve kıstasları. Uyuşmazlık Mahkemesi Dergisi, 7, 373-398.

Demir, F. (2005). Yerel özerklik kavramı üzerine bir inceleme. H. Özgür ve M. Kösecik (Ed), Yerel yönetimler üzerine güncel yazılar I. içinde (ss. 275-296). Ankara: Nobel Yayınları.

Erol, F., Ö. (2020). Cumhurbaşkanlığı hükümet sisteminde Cumhurbaşkanlığı politika kurulları. Marmara Üniversitesi Hukuk Fakültesi Hukuk Araştırmaları Dergisi, 26 (1), 107-130.

Eryılmaz, B. (2010). Kamu yönetimi. 3. Baskı. Ankara: Okutman Yayınları.

Gençay Sevgili, D. F. (2018). Belediye şirketlerinin hukuki statüsü. Türkiye Barolar Birliği Dergisi, 134, 153-176.

Gözler, K. (2003). İdare hukuku. Bursa: Ekin Yayınları.

Gözler, K. (2018). Mahalli idareler hukukuna giriş. Bursa: Ekin Yayınları.

Gözübüyük, Ş. (2003). Yönetim hukuku. 18. Baskı. Ankara: Turhan Kitabevi.

Gözübüyük, Ş. ve Tan, T. (2001). İdare hukuku. 2. Baskı. Ankara: Turhan Kitabevi.

İsbir, B. (2010). Temsili demokrasi anlayışına göre yerel yönetimlerde özerklik. Dokuz Eylül Hukuk Fakültesi Dergisi, 11, 1571-1599.

Kalabalık, H. (2008). İdare hukukunun temel kavram ve kurumları. Sakarya.

Kamu İktisadi Teşebbüsleri Hakkında Kanun Hükmünde Kararname. Kararname No: 233. R.G. Tarihi: 18/06/1984. R.G. Sayıs1: 18435.

Karahanoğulları, O. (2013). Yerel özerklik: mahalli müşterek ihtiyaçların yerinden yönetimi. Beşinci Ulusal Yerel Yönetimler Sempozyumu içinde (65-97). Ankara: Türkiye Belediyeler Birliği Yayınları.

Keleş, R. (2006). Yerinden yönetim ve siyaset. İstanbul: Cem Yayınları.

Medeni Kanun. Kanun No: 4721. R.G. Tarihi: 08/12/2001. R.G. Say1s1: 24607.

Öner, Ş. (2006). Yeni mevzuat çerçevesinde Türkiye'de belediye yönetimi. Ankara: Nobel Yayınlar1.

Örselli, E., Babahanoğlu, V. ve Bilici, Z. (2018). Kamu politikalarında yeni aktörler: Cumhurbaşkanlığı politika kurulları ve ofisleri. Turkish Studies, 13 (30), 303-318.

Sobacı, M. Z. ve Köseoğlu, Ö. (2016). Başkanlık sistemlerinde yerel yönetimler. Ankara: SETA Yayınları.

Sobacı, M. Z., Miş, N. ve Köseoğlu, Ö. (2018). Türkiye'nin yeni yönetim modeli ve Cumhurbaşkanlığ̀ Teşkilatı, SETA Perspektif, 206, 1-6.

Şengül, R. (2010). Yerel yönetimler. Kocaeli: Umuttepe Yayınları.

Tortop, N. (1999). Mahalli idareler. 6. Baskı. Ankara: Yarg1 Yayınları.

Tortop, N., İsbir, G. E., Aykaç, B., Yayman H. ve Özer, M. A. (2017). Yönetim bilimi. 11. Baskl. Ankara: Nobel Yayınları.

Turan, M. (2018). Türkiye'nin yeni yönetim düzeni: Cumhurbaşkanlığı hükümet sistemi. Social Sciences Research Journal, 7(3), 42-90.

Türkiye Cumhuriyeti Anayasası. Kanun No: 2709. R.G. Tarihi: 09/11/1982. R.G. Sayıs1: 17863. 
Türkiye Cumhuriyeti Anayasasında Değişiklik Yapılmasına Dair Kanun. Kanun No: 6771. R.G. Tarihi: 11/02/2017. R.G. Say1s1: 29976.

Ulusoy, A. ve Akdemir, T. (2009). Yerel yönetimler ve mali özerklik: Türkiye ve OECD ülkelerinin karşılaştırmalı analizi. Balıkesir Üniversitesi Sosyal Bilimler Enstitüsü Dergisi, 12(21), 259-287.

Üstün, G. (2019). Cumhurbaşkanlığı ofislerinin idari teşkilattaki yeri. Cumhurbaşkanlı̆̆ Sisteminde Yürütme Sempozyum Bildiri Kitabı içinde (29-34). İstanbul: Marmara Üniversitesi Yayınevi.

Yontar, G. İ. ve Dağ, M. (2014). Avrupa yerel yönetimler özerklik şartı çerçevesinde Türkiye'de mali özerklik. Uluslararası Yönetim ve Işsletme Dergisi, 10 (21), 147-162.

Yontar, G. İ. ve Özer, Y. E. (2018). Yerel demokrasinin kalite göstergesi olarak idari ve mali denetim. Hukuk ve İktisat Araştırmaları Dergisi, 10 (2), 99-110.

Yükseköğretim Kanunu. Kanun No: 2547. R.G. Tarihi: 06/11/1981. R.G. Sayıs1: 17506.

\section{ETİK ve BİLIMSEL İLKELER SORUMLULUK BEYANI}

$\mathrm{Bu}$ çalışmanın tüm hazırlanma süreçlerinde etik kurallara ve bilimsel atıf gösterme ilkelerine riayet edildiğini yazar beyan eder. Aksi bir durumun tespiti halinde Afyon Kocatepe Üniversitesi Sosyal Bilimler Dergisi'nin hiçbir sorumluluğu olmayıp, tüm sorumluluk makale yazarlarına aittir.

\section{ARAŞTIRMACILARIN MAKALEYE KATKI ORANI BEYANI}

1. yazar katk1 oran1 : \%100 